\title{
Praktik Penyusunan Peraturan Desa (Perdes) sebagai Penguatan Desa Tangguh Bencana di Kabupaten Malang
}

\author{
Yana Syafriyana Hijri \\ Fakultas Ilmu Sosial dan Ilmu Politik, Universitas Muhammadiyah Malang \\ yana@umm.ac.id \\ Wahyudi Kurniawan \\ Fakultas Hukum, Universitas Muhammadiyah Malang \\ syafrieyeha79@gmail.com \\ Yusuf Adam Hilman \\ Fakultas Ilmu Sosial dan Ilmu Politik, Universitas Muhammadiyah Ponorogo \\ 545471adamongis@gmail.com
}

Naskah diterima: 19 November 2019| Naskah disetujui: 10 Januari 2020

\begin{abstract}
Disaster management (DM) gets a new dimension with the ratification of Law No. 24 (2007) on disaster management followed some related rules. DM as an thorough effort is started by disaster risk reduction, emergency, rehabilitation, and reconstruction. Based on the authority, DM needs to be in a comprehensive policy level ranging from national, regional, up to the village scope as a front guard of the government, though DM is not only the responsibility of government, where the people have to also actively participate. Pujiharjo Village, Tirtoyudo District, Malang, is one of villages potentially affected by natural disasters, ranging from erosion and flooding. This village as the smallest government unit interacting with the community, has policies that are poured into village regulations (Perdes) about the disaster management with local knowledge to reduce disaster risk. Thus, the community is expected to be tougher because they can anticipate and minimize the disaster risk by breakthrough adaptation, ability to handle and keep the structure, and function certain basic in times of disasters. Even if affected by any disaster, they would quickly rebuild into normal or at least can independently recover. Desa Tangguh (Tough Village) as a national program of $B N P B$, can also act as the responsibility of a government against people in the disaster management.
\end{abstract}

Keyword: Disaster Management, Regulations, Village 


\begin{abstract}
Abstrak
Penanggulangan bencana (PB) mendapat dimensi baru dengan diterbitkannya UU No. 24 (2007) tentang penanggulangan bencana yang diikuti beberapa aturan terkait. PB sebagai upaya menyeluruh dan proaktif dimulai dari pengurangan risiko bencana, tanggap darurat, rehabilitasi, dan rekonstruksi. Berdasarkan kewenangannya, PB perlu memiliki kebijakan komprehensif mulai dari tingkat nasional, regional, hingga ruang lingkup desa sebagai ujung tombak pemerintahan, meski PB bukan hanya tanggung jawab pemerintah, di mana rakyat juga harus ikut aktif. Desa Pujiharjo, Kecamatan Tirtoyudo, Malang, adalah salah satu desa yang berpotensi terkena bencana alam, mulai dari erosi hingga banjir. Desa ini sebagai unit pemerintah terkecil yang berinteraksi dengan masyarakat, memiliki kebijakan yang dituangkan ke dalam peraturan desa (Perdes) tentang manajemen bencana dengan pengetahuan lokal untuk mengurangi risiko bencana. Dengan demikian, masyarakat diharapkan lebih tangguh karena mereka dapat mengantisipasi dan meminimalkan risiko bencana dengan melakukan terobosan adaptasi, kemampuan menangani dan menjaga struktur, dan fungsi dasar tertentu pada saat bencana. Bahkan jika terdampak bencana, mereka akan dengan cepat membangun kembali hingga normal atau setidaknya dapat pulih secara mandiri. Desa Tangguh sebagai program nasional BNPB, juga dapat berperan sebagai tanggung jawab pemerintah terhadap masyarakat dalam manajemen bencana.
\end{abstract}

Kata kunci: Penanggulangan Bencana, Paraturan, Desa

\title{
Pendahuluan
}

Pola penanggulangan bencana mendapatkan dimensi baru dengan dikeluarkannya UndangUndang No. 24 tahun 2007 tentang Penanggulangan Bencana yang diikuti beberapa aturan pelaksana terkait, yaitu Peraturan Presiden No. 08 tahun 2008 tentang Badan Nasional Penanggulangan Bencana, Peraturan Pemerintah (PP) No. 21 tahun 2008 tentang Penyelenggaraan Penanggulangan Bencana, PP No. 22 tahun 2008 tentang Pendanaan dan Pengelolaan Bantuan Bencana, dan PP No. 23 tahun 2008 tentang Peran Serta Lembaga Internasional dan Lembaga Asing non Pemerintah dalam Penanggulangan Bencana. Dimensi baru dari rangkaian peraturan terkait dengan bencana tersebut adalah: Pertama, penanggulangan bencana sebagai sebuah upaya menyeluruh dan proaktif dimulai dari pengurangan risiko bencana, tanggap darurat, dan rehabilitasi dan rekonstruksi. Kedua, penanggulangan bencana sebagai upaya yang dilakukan bersama oleh para pemangku kepentingan dengan peran dan fungsi yang saling melengkapi. Ketiga, penanggulangan bencana sebagai bagian dari proses pembangunan sehingga mewujudkan ketahanan (resilience) terhadap bencana (Organisasi-DKP, 2017).

Pemerintah Pusat dan Pemerintah Daerah menjadi penanggungjawab dalam penyelenggaraan penanggulangan bencana, baik pada peristiwa bencana alam, bencana nonalam, maupun bencana sosial. Adapun tanggung jawab Pemerintah Pusat dalam hal ini meliputi: (1) Pengurangan risiko bencana dan pemaduan pengurangan risiko bencana dengan program pembangunan; (2) Pelindungan masyarakat dari dampak bencana; (3) Penjaminan pemenuhan hak 
masyarakat dan pengungsi yang terkena bencana secara adil dan sesuai dengan standar pelayanan minimum; (4) Pemulihan kondisi dari dampak bencana; (5) Pengalokasian anggaran penanggulangan bencana dalam anggaran pendapatan dan belanja negara yang memadai; (6) Pengalokasian anggaran penanggulangan bencana dalam bentuk dana siap pakai (dana pemerintah yang dicadangkan merupakan dana siap pakai apabila terjadi bencana); dan (7) Pemeliharaan arsip/dokumen otentik dan kredibel dari ancaman dan dampak bencana (Organisasi-DKP, 2017)

Sedangkan kewenangan pusat dalam penanggulangan bencana yaitu: (1) Penetapan kebijakan penanggulangan bencana selaras dengan kebijakan pembangunan nasional; (2) Pembuatan perencanaan pembangunan yang memasukkan unsur-unsur kebijakan penanggulangan bencana; (3) Penetapan status dan tingkatan bencana nasional dan daerah; (4) Penentuan kebijakan kerja sama dalam penanggulangan bencana dengan negara lain, badan-badan, atau pihak-pihak internasional lain; (5) Perumusan kebijakan tentang penggunaan teknologi yang berpotensi sebagai sumber ancaman atau bahaya bencana; (5) Perumusan kebijakan mencegah penguasaan dan pengurasan sumber daya alam yang melebihi kemampuan alam untuk melakukan pemulihan; dan (7) Pengendalian pengumpulan uang atau barang yang bersifat nasional (termasuk pemberian izin pengumpulan uang atau barang yang bersifat nasional menjadi kewenangan Menteri Sosial).

Adapun penetapan status dan tingkat bencana nasional dan daerah memuat indikator yang meliputi: jumlah korban; kerugian harta benda; kerusakan prasarana dan sarana; cakupan luas wilayah yang terkena bencana; dan dampak sosial ekonomi yang ditimbulkan. Ketentuan lebih lanjut mengenai penetapan status dan tingkatan bencana diatur dengan peraturan presiden.

Kemudian tanggung jawab pemerintah daerah dalam penanggulangan bencana meliputi: (1) Penjaminan pemenuhan hak masyarakat dan pengungsi yang terkena bencana sesuai dengan standar pelayanan minimum; (2) Pelindungan masyarakat dari dampak bencana; (3) Pengurangan risiko bencana dan pemaduan pengurangan risiko bencana dengan program pembangunan; dan (4) Pengalokasian dana penanggulangan bencana dalam anggaran pendapatan belanja daerah yang memadai. Dengan kewenangannya dalam hal penetapan kebijakan penanggulangan bencana pada wilayahnya selaras dengan kebijakan pembangunan daerah. Kemudian pembuatan perencanaan pembangunan yang memasukkan unsur-unsur kebijakan penanggulangan bencana.

Berdasarkan kewenangannya, maka upaya penanggulangan bencana di daerah perlu dimulai dengan adanya kebijakan daerah yang bertujuan menanggulangi bencana sesuai dengan peraturan yang ada. Strategi yang ditetapkan daerah dalam menanggulangi bencana perlu disesuaikan dengan kondisi daerah. Operasi penanggulangan bencana perlu dipastikan efektif, efisien dan berkelanjutan. Demikian untuk mendukung pengembangan sistem penanggulangan bencana yang mencakup 
kebijakan, strategi, dan operasi secara nasional mencakup pemerintah pusat dan daerah maka dipandang perlu dimulai dengan mengetahui sejauh mana penerapan peraturan yang terkait dengan penanggulangan bencana di daerah.

Namun demikian permasalahan bencana tidak hanya tanggung jawab pemerintahan saja tapi juga masyarakatnya harus secara aktif ikut serta sebagai bentuk partisipatif. Masyarakat yang tangguh bencana ialah masyarakat yang mampu mengantisipasi dan meminimalisir kekuatan yang merusak, melalui adaptasi. Mereka juga mampu mengelola dan menjaga struktur dan fungsi dasar tertentu ketika terjadi bencana. Dan jika terkena dampak bencana, mereka akan dengan cepat bisa membangun kehidupannya menjadi normal kembali atau paling tidak dapat dengan cepat memulihkan diri secara mandiri.

Desa Tangguh merupakan program nasional yang diusulkan BNPB (Badan Nasional Penanggulangan Bencana) sebagaimana Peraturan Kepala BNPB No. 01 Tahun 2012 tentang pedoman umum desa/kelurahan tangguh bencana, sebagai upaya mewujudkan Indonesia Tangguh. Program ini merupakan wujud tanggung jawab pemerintah terhadap masyarakatnya dalam hal PB. Karena masyarakat yang merupakan penerima dampak langsung dari bencana, dan sekaligus sebagai pelaku pertama dan langsung yang akan merespon bencana di sekitarnya, maka masyarakat perlu dibekali dalam konteks pemberdayaan agar menjadi tangguh, bukan hanya siap menghadapi bencana tapi menjadi TANGGUH (Bencana, 2010).

Program Desa Tangguh Bencana (Destana) dilakukan dengan pemberdayaan masyarakat disertai pendampingan teknis dari pemerintah melalui kegiatan mitigasi non-struktural dan mitigasi struktural. Artinya, secara paralel perlu dilaksanakan penguatan kapasitas masyarakatnya dan penguatan kapasitas lingkungannya dengan mengoptimalkan kearifan lokal (local widom) agar masyarakat punya kemandirian dalam menghadapi bencana di tingkat desa.

Desa sebagai satuan pemerintahan terkecil yang langsung berinteraksi dengan masyarakat. Desa dengan kultur masyarakat dapat lebih terpelihara dan dikembangkan dengan produktif untuk kehidupan dan penghidupan, di tingkat desa tempat dilaksanakannya berbagai program pemberdayaan masyarakat serta adanya kearifan lokal yang kuat yang harus diakomodasi dalam pengurangan resiko bencana.

Desa Pujiharjo Kecamatan Tirtoyudo Kabupaten Malang merupakan daerah yang berpotensi terdampak bencana alam, terutama longsor dan banjir. Pada September 2016, misalnya, bencana banjir kembali melanda Dusun Blok Songo, Desa Pujiharjo, Kecamatan Tirtoyudo, Kabupaten Malang. Terjangan air bercampur lumpur itu disebabkan sungai di wilayah RT 09 RW 02 tidak mampu menampung luapan air hujan selama beberapa hari. Puncaknya, hujan terjadi hari Rabu, 
tanggal 14 September 2016 pada malam hari, mulai pukul 21.30. Tingginya intensitas hujan mengakibatkan sungai di Pujiharjo tak mampu menampung luapan air sehingga menerjang kawasan pemukiman sekitar pukul 22.30. Adapun banjir bandang ini mengakibatkan banyak kerusakan, di antaranya satu rumah hanyut, sepuluh rumah rusak berat, tiga puluh rumah rusak ringan, rusaknya jembatan dan tanggul jebol, selain itu ada pula beberapa hewan ternak yang ikut hanyut dihempas banjir. Kejadian longsor juga sebenarnya akibat dari banjir, karena pengerukan sungai akibat bencana alam beberapa bulan sebelumnya yang belum pulih, sehingga aliran air tidak banyak melewati sungai, melainkan langsung menghantam badan jalan dan rumah penduduk, akibatnya akses jalan tertutup karena material longsoran (Rizkasandi, 2015).

Dengan kejadian tersebut diperlukan daya ketangguhan masyarakat dalam mengahadapi bencana, sebelum bantuan dari pemerintah melalui BPBD, PMI, regu pencarian dan pertolongan, dan lembaga bantuan lainnya, maka kesiapsiagaan dalam darurat bencana itu diperlukan. Adapun ketangguhan terhadap bencana bercermin pada, pertama, kemampuannya dalam memiliki daya antisipasi yaitu apabila masyarakat sudah mempunyai wawasan tentang kebencanaan. Kedua, daya proteksi yaitu apabila sudah mempersiapkan diri pada sarana yang dimiliki. Ketiga, daya adaptasi yaitu apabila sudah berpedoman pada konsep pengurangan resiko bencana dan daya lenting apabila sudah mempunyai modal sosial untuk kembali normal (Saptadi, 2015).

Berdasarkan pengabdian yang dilaksanakan di Desa Pujiharjo tahun 2016 mengenai penguatan kapasitas Desa Tangguh Bencana, sebenarnya desa ini sudah masuk dalam klasifikasi Destana tingkat madya, meski belum memiliki dasar imperatif dalam penyelenggaran penanggulangan bencana, secara kelembagaan sudah ada struktur yang mengurusi sendiri PB di tingkat pemerintahan Desa, sedangkan masyarakat diwadahi dalam SIBAT, yaitu kelompok atau komunitas siaga bencana berbasis masyarakat yang disiapkan secara khusus fungsinya untuk membantu penyelenggaraan PB. SIBAT melalui kegiatan Palang Merah Indonesia (PMI) diberikan pendidikan dan pelatihan dalam hal kedaruratan atau merespon situasi ketika terjadi bencana. Melalui komunitas tersebut diberikan pengetahuan dan pemahaman awal jika terjadi bencana dan tindakan-tindakan apa saja yang harus dilakukan oleh masyarakat.

Menjadi persoalan ketika penyelenggaraan PB tidak didukung dengan kebijakan yang mengatur secara komprehensif mengenai tugas dan fungsi Pemerintah Desa, Lembaga PB Desa, Lembaga lainnya yang terkait, termasuk juga persoalan pendanaan mulai dari pra bencana, saat bencana dampai dengan pasca bencana yang semestinya bisa masuk kedalam RPMDes dan RKPDes sebagai prioritas program Pemerintah Desa, hal tersebut termasuk dana cadangan yang disusun kedalam RAPBDes. Hal tersebut yang melatarbelakangi pentingannya Perdes tentang 
Penyelenggaraan PB. Dengan adanya Perdes tersebut maka penyelenggaraan PB di Desa lebih terencana, teratur, lebih siap jika suatu saat akan terjadi bencana.

\section{Metode}

Metode pendekatan yang digunakan dalam kegiatan ini yaitu dengan melakukan pendampingan, pendidikan, dan pelatihan sebagai upaya meningkatkan kemampuan mitra, dalam hal ini perangkat desa, pengurus lembaga desa, dan masyarakat pada umumnya dalam mengetahui dan memahami penyusunan produk hukum/perdes Desa Tangguh Bencana.

Dengan memberikan pendampingan, pendidikan, dan pelatihan mengenai penyusunan produk hukum/perdes tentang desa tangguh bencana pada mitra, diharapkan kapasitas atau kemampuannya dalam mengetahui dan memahami tahapan penyusunan produk hukum/perdes desa tangguh bencana sehingga tujuan untuk mewujudkan penguatan desa tangguh bencana dapat dilaksanakan.

Beberapa rencana kegiatan disesuaikan dengan jenis luaran pendampingan penyusunan perdes sebagai upaya penguatan kapasitas desa tangguh bencana sesuai dengan kebutuhan bagi perangkat desa, pengurus lembaga desa, tim relawan desa, dan masyarakat setempat dengan tawaran solusi atas persoalan yang dihadapi dalam penyelenggaraan penanggulangan bencana, sebagaimana terdapat dalam tabel 1.

Tabel 1. Rencana Program dan Tawaran Solusi Bagi Mitra

NO.

1 Penyuluhan Manajemen Bencana

1.1. Mitigasi Bencana

1.2. Kesiapsiagaan Bencana

1.3. Tanggap Darurat

1.4. Rehabilitasi dan Rekonstruksi

2 Pelatihan Penyusunan Produk Hukum

2.1. Survei/Riset tentang objek Perdes

2.2. Melakukan analisis akademik tentang

2.3. persoalan yang akan diatur oleh Peraturan

2.4. Desa (Perdes)

2.5. Tata cara penyusunan \& pembahasan Draft

2.6. Perdes

2.7. Tata cara melakukan uji Publik Perdes

Tata cara pembahasan akhir Perdes

Tata cara pengesahan Perdes

Tata cara pengundangan atau penyebarluasan Perdes

3 Pendampingan Penyusunan Rancangan Perdes tentang Desa Tangguh Bencana

\section{TAWARAN SOLUSI}

1. Memberikan pengetahuan dan pemahaman tentang pentingnya pengelolaan bencana.

2. Memberikan pengetahuan dan pemahaman tentang penyelenggaraan $\mathrm{PB}$.

3. Memberikan pengetahuan dan pemahaman tentang Destana.

1. Memberikan pengetahuan dan pemahaman mengenai produk hukum desa dan beberapa aspek penting mengenai produk hukum desa khususnya PERDES.

2. Memberkan pengetahuan dan ketrampilan dalam penyusunan Produk Hukum Desa (PERDES).

1. Terbentuknya Draft Naskah Peraturan Desa tentang Desa Tangguh Bencana

2. Penyelenggaraan uji publik partisipatoris untuk menyempurnakan draft perturan desa tentang desa tangguh bencana

Sumber: diolah dari hasil pengabdian 
Dalam kegiatan pendampingan penyusunaan perdes sebagai upaya penguatan kapasitas desa tangguh bencana di Desa Pujiharjo Kabupaten Malang, akan membutuhkan partisipasi mitra, selain perangkat daerah, pengurus lembaga desa, tim relawan, dan masyarakat (Tabel 2).

Tabel 2 Partisipasi Mitra

\begin{tabular}{|c|c|c|}
\hline No. & Unsur Mitra & Partisipasi \\
\hline 1. & $\begin{array}{l}\text { Perangkat Desa (Kepala Desa, Sekdes, Kepala } \\
\text { Urusan (Kaur), Kepala dusun (Kasun), Tim } \\
\text { Relawan dan Masyarakat. }\end{array}$ & $\begin{array}{l}\text { a. Menyiapkan tempat kegiatan. } \\
\text { b. Ikut serta dalam menyusun jadwal } \\
\text { kegiatan. } \\
\text { c. Mengkoordinasikan kegiatan dengan } \\
\text { lembaga lain dan masyarakat desa. } \\
\text { d. Mengikuti pendidikan dan pelatihan } \\
\text { tentang pentingnya Manajemen } \\
\text { Bencana. } \\
\text { e. Mengikuti pendidikan dan pelatihan } \\
\text { tentang penyelenggaran PB. } \\
\text { f. Mengikuti pendampingan penyusunan } \\
\text { produk hukum/perdes desa tangguh } \\
\text { bencana. }\end{array}$ \\
\hline 2. & $\begin{array}{l}\text { Lembaga Desa (Anggota BPD, Pengurus: LPMD, } \\
\text { PKK, dan Karang Taruna, dll) }\end{array}$ & $\begin{array}{l}\text { a. Mengikuti pendidikan dan pelatihan } \\
\text { tentang pentingnya Manajemen } \\
\text { Bencana. } \\
\text { b. Mengikuti pendidikan dan pelatihan } \\
\text { tentang penyelenggaran PB. } \\
\text { c. Mengikuti pendampingan penyusunan } \\
\text { produk hukum/perdes desa tangguh } \\
\text { bencana. }\end{array}$ \\
\hline
\end{tabular}

Sumber: diolah dari hasil pengabdian

\section{Hasil dan Pembahasan}

Pendampingan penyusunan peraturan Desa (Perdes) sebagai upaya penguatan kapasitas desa tangguh bencana dimaksudkan bahwa desa memiliki dasar hukum dalam pengelolaan bencana mulai dari pra bencana, saat bencana, dan pasca bencana dengan melaksanakan aktivitas pengelolaan resiko bencana, kedaruratan, dan pemulihan sebagaimana dalam Gambar 1.

Gambar 1. Kerangka Berfikir Manajemen Bencana

Sumber: diolah dari hasil pengabdian

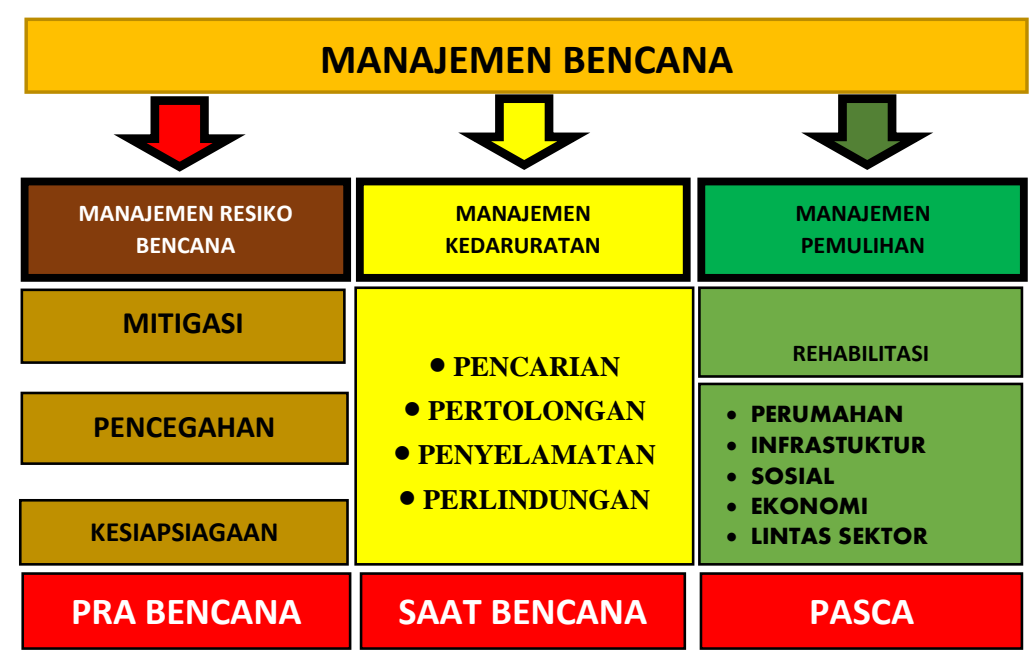


Berdasarkan gambar tersebut di atas dapat dijelaskan bahwa dalam pengelolaan kebencanaan terdapat tiga tahapan. Pertama, masa pra bencana yaitu adanya pengelolaan resiko bencana seperti mitigasi, pencegahan, dan kesiapsiagaan. Kedua, masa saat bencana yaitu adanya pengelolaan kedaruratan bencana dengan kegiatan pencarian, pertolongan, penyelamatan, dan perlindungan terhadap korban bencana. Terakhir, pasca bencana yaitu pengelolaan pemulihan terhadap orang, benda, atau pun wilayah bencana dengan melaksanakan rehabilitasi dan rekonstruksi baik perumahan, infrastruktur, kehidupan sosial, ekonomi, dan perosalan lintas sektor lainnya.

Adapun indikator Desa Tangguh Bencana berdasarkan Peraturan Kepala (Perka) BNPB No. 1 Tahun 2012, tentang Pedoman Penyusunan Desa/Kelurahan Tangguh Bencana antara lain: 1) Dasar Hukum (legal basic) atau kebijakan PB yaitu berupa perdes atau aturan setingkatnya; 2) Perencanaan antara lain seperti Rencana PB, Rencana Kontijensi, Rencana PRB, dll.; 3) Kelembagaan seperti terbentuknya Tim PB, Tim PRB, Tim Relawan, Tim Jitupasna, dll.; 4) Pengembangan Kapasitas berupa kegiatan Diklat, Simulasi dan Gladi; 5) Upaya sistematis pengelolaan dan PB seperti pendanaan evakuasi, pendanaan kontijensi dan pendanaan rehabilitasi dan rekonstruksi. Model desa tangguh bencana tersebut sebagaimana tedapat dalam Tabel 3.

Tabel 3 Model Desa Tangguh Bencana

\begin{tabular}{|c|c|c|c|c|}
\hline \multirow{2}{*}{ No. } & \multirow{2}{*}{ Indikator } & \multicolumn{3}{|c|}{ Model Desa Tangguh Bencana } \\
\hline & & Utama & Madya & Pratama \\
\hline 1. & $\begin{array}{c}\text { Legal Basic/ } \\
\text { Kebijakan }\end{array}$ & $\begin{array}{l}\text { 1. Adanya kebijakan } \\
\text { Pengurangan Resiko } \\
\text { Bencana (PRB) yang } \\
\text { telah dilegalkan dalam } \\
\text { bentuk Perdes. } \\
\text { 2. Atau perangkat hukum } \\
\text { setingkat. }\end{array}$ & $\begin{array}{l}\text { Adanya kebijakan PRB } \\
\text { yang tengah } \\
\text { dikembangkan di } \\
\text { tingkat desa. }\end{array}$ & $\begin{array}{l}\text { Adanya upaya-upaya } \\
\text { awal untuk menyusun } \\
\text { kebijakan PRB di tingkat } \\
\text { desa. }\end{array}$ \\
\hline 2. & Perencanaan & 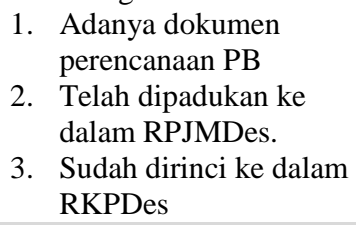 & $\begin{array}{l}\text { 1. Adanya dokumen } \\
\text { perencanaan PB yang } \\
\text { telah tersusun } \\
\text { 2. Belum terpadu ke } \\
\text { dalam instrumen } \\
\text { perencanaan desa }\end{array}$ & $\begin{array}{l}\text { Adanya upaya-upaya } \\
\text { awal untuk menyusun } \\
\text { dokumen perencanaan } \\
\text { PB }\end{array}$ \\
\hline \multirow{2}{*}{ No. } & & \multicolumn{3}{|c|}{ Model Desa Tangguh Bencana } \\
\hline & Munator & Utama & Madya & Pratama \\
\hline 3. & $\begin{array}{c}\text { Kelembagaa } \\
n\end{array}$ & $\begin{array}{l}\text { 1. Adanya forum PRB } \\
\text { beranggotakan wakil- } \\
\text { wakil masyarakat, } \\
\text { termasuk kelompok } \\
\text { perempuan dan } \\
\text { kelompok rentan, dan } \\
\text { wakil pemerintah desa } \\
\text { 2. Berfungsi dengan } \\
\text { aktif. } \\
\text { 3. Adanya tim relawan } \\
\text { PB Desa/Kelurahan } \\
\text { yang secara rutin } \\
\text { terlibat aktif. }\end{array}$ & $\begin{array}{l}\text { 1. Adanya forum PRB } \\
\text { beranggotakan wakil- } \\
\text { wakil masyarakat, } \\
\text { kelompok perempuan } \\
\text { dan kelompok rentan } \\
\text { 2. Belum berfungsi } \\
\text { penuh dan aktif } \\
\text { 3. Adanya tim relawan } \\
\text { PB Desa/Kelurahan } \\
\text { yang terlibat }\end{array}$ & $\begin{array}{l}\text { 1. Adanya upaya-upaya } \\
\text { awal untuk } \\
\text { membentuk forum } \\
\text { PRB yang } \\
\text { beranggotakan wakil- } \\
\text { wakil dari masyarakat } \\
\text { 2. Adanya upaya awal } \\
\text { untuk membentuk tim } \\
\text { relawan PB desa. }\end{array}$ \\
\hline
\end{tabular}


4.

$\begin{array}{cl}\text { Pendanaan } & \begin{array}{c}\text { 1. Ada upaya awal } \\ \text { pengajuan dana PB. }\end{array} \\ & \begin{array}{c}\text { 2. Ada upaya awal } \\ \text { penyusunan } \\ \text { mekanisme. }\end{array} \\ & \\ \text { Pengembang } & \begin{array}{l}\text { 1. Adanya kegiatan } \\ \text { peningkatan kapasitas, }\end{array} \\ & \text { pengetahuan dan } \\ & \text { pendidikan } \\ & \text { kebencanaan bagi para } \\ & \text { anggotanya dan } \\ & \text { masyarakat pada } \\ & \text { umumnya } \\ \text { 2. Adanya upaya-upaya } & \text { sistematis untuk } \\ & \text { mengadakan } \\ & \text { pengkajian risiko, } \\ & \text { manajemen risiko dan } \\ & \text { pengurangan } \\ & \text { kerentanan. } \\ \text { 3. Adanya kegiatan- } \\ \text { kegiatan ekonomi } \\ \text { produktif alternatif } \\ \text { untuk mengurangi } \\ \text { kerentanan }\end{array}$

1. Ada upaya pengajuan dana PB (on process).

2. Ada upaya penyusunan mekanisme pencairan dana PB.

1. Adanya kegiatan peningkatan kapasitas, pengetahuan \& pendidikan kebencanaan bagi para anggota \& masyarakat pada umumnya.

2. Adanya upaya-upaya mengadakan pengkajian \& manajemen risiko, pengurangan kerentanan.

3. Adanya kegiatankegiatan ekonomi produktif alternatif untuk mengurangi kerentanan, tetapi belum terlalu teruji
1. Tersedianya dana PB.

2. Tersusunnya mekanisme pencairan dana PB yang telah dilegalkan melalui Perdes atau setingkatnya.

1. Adanya upaya-upaya awal untuk mengadakan pengkajian risiko, manajemen risiko dan pengurangan kerentanan

Sumber: diolah dari hasil pengabdian

Dengan demikian, salah satu komponen pembentukan desa tangguh bencana berdasarkan tabel di atas yaitu adanya legislasi atau dasar hukum terbentuknya desa tangguh bencana. Pembentukan desa tangguh bencana di Kabupaten Malang sampai dengan saat ini, tidak diikuti dengan pembentukan dasar hukum dalam bentuk peraturan desa, bahkan sepenuhnya diserahkan kepada Pemerintah Desa masing-masing. Selanjutnya, persoalan baru kemudian muncul bersamaan dengan itu kemampuan sumber daya manusia yang ada dalam struktur pemerintahan desa terutama Kepala Desa, Sekretaris Desa, Lembaga Pemberdayaan Masyarakat Desa (LPMD), dan Badan Permusyawaratan Desa (BPD) terhadap pengetahuan dan tata cara pembuatan peroduk hukum desa (legal drafting) sangat minim.

Hal tersebut dapat dilihat juga bahwa produk hukum dalam bentuk Perdes yang dibuat oleh pemerintah Desa Pujiharjo tidaklah banyak, padahal perdes merupakan produk hukum yang dibentuk oleh pemerintahan desa sebagai alat kewenangan dalam menjalankan pemerintahan dan membangun desa berdasarkan urusan dan kepentingan desa masing-masing. Maka perdes dianggap penting dalam penyelenggaraan pemerintahan dan pembangunan desa, termasuk di dalamnya adalah upaya penanggulangan bencana.

Jenis luaran yang akan dihasilkan sesuai dengan rencana kegiatan pengabdian ini, yakni sebagaimana dalam Tabel 4. 
Tabel 4 Pendampingan Penyusunan Perdes Desa Tangguh Bencana

\section{NO.}

1 Penyuluhan Manajemen Bencana

1.1. Mitigasi Bencana

1.2. Kesiapsiagaan Bencana

1.3. Tanggap Darurat

1.4. Rehabilitasi dan Rekonstruksi

2 Pelatihan Penyusunan Produk Hukum

2.1. Survei/Riset tentang objek Perdes

2.2. Melakukan analisis akademik tentang persoalan yang akan diatur oleh Peraturan Desa (Perdes)

2.3. Tata cara penyusunan \& pembahasan Draft Perdes

2.4. Tata cara melakukan uji Publik Perdes

2.5. Tata cara pembahasan akhir Perdes

2.6. Tata cara pengesahan Perdes

2.7. Tata cara pengundangan atau penyebarluasan Perdes

3 Pendampingan Penyusunan Rancangan Perdes tentang Desa Tangguh Bencana;
HASIL PROGRAM

Jasa/Produk

Jasa/Produk

Jasa/Produk

Sumber: diolah dari hasil pengabdian

\section{Kesimpulan}

Peraturan Kepala BNPB No. 01 Tahun 2012 tentang Pedoman umum desa/kelurahan tangguh bencana, sebagai upaya mewujudkan Indonesia Tangguh. Program ini merupakan wujud tanggungjawab pemerintah terhadap masyarakatnya dalam hal PB. Karena masyarakat yang merupakan penerima dampak langsung dari bencana, dan sekaligus sebagai pelaku pertama dan langsung yang akan merespon bencana di sekitarnya, maka masyarakat perlu dibekali dalam konteks pemberdayaan agar menjadi Tangguh. Adapun ketangguhan terhadap bencana bercermin pada kemampuannya dalam memiliki daya antisipasi, daya proteksi, dan daya adaptasi terhadap bencana.

\section{Pernyataan}

Terima kasih kepada semua pihak yang telah membantu dan memberikan dukungan bagi terlaksananya program pengabdian ini, selain itu kami haturkan kepada lembaga atau institusi yakni Program Studi Ilmu Pemerintahan, Fakultas Ilmu Sosial dan Ilmu Politik, Universitas Muhammadiyah Malang. 


\section{Referensi}

Bencana, B. N. (2010). Peraturan Kepala Badan Nasional Penanggulangan Bencana (BNPB) Nomor 1 Tahun 2012 Tentang Pedoman Umum Desa/Kelurahan Tangguh Bencana. Jakarta: ditjenpp.kemenkumham.go.id.

Organisasi-DKP, S. H. (2017). Undang-Undang Republik Indonesia Nomor 24 Tahun 2007 Tentang Penanggulangan Bencana. Jakarta: SJDI/Biro Hukum dan Organisasi-DKP.

Rizkasandi, H. (2015, Mei). http://www.malangtimes.com/baca/14357/20160915/135438/banjirbandang-pujiharjo-1-rumah-hanyut-puluhan-rusak-berat/. Dipetik 2016, dari www.malangtimes.com:

http://www.malangtimes.com/baca/14357/20160915/135438/banjir-bandang-pujiharjo-1rumah-hanyut-puluhan-rusak-berat/

Saptadi, G. (2015, April 16). Destana : Desa Tangguh Bencana. Artikel Opini Harian Kedaulatan Rakyat. 
Praktik Penyusunan Peraturan Desa (Perdes) sebagai Penguatan Desa Tangguh Bencana di Kabupaten Malang Yana Syafriyana Hijri, dkk 